Paper proposal for the 2015 Historical Network Research Conference

Lisbon, 15-18 September 2015

\title{
The evolution of Japanese business networks in ASEAN countries since the 1960s
}

Keywords (3): Japanese overseas subsidiaries, keiretsu, ethnic Chinese

Authors: Jean-Pascal Bassino, Pablo Jensen, and Matteo Morini

Institutional affiliation, contact details, and brief bio of the authors

Jean-Pascal Bassino is professor of economics at Ecole Normale Supérieure de Lyon (France), a national graduate school, and director of the Institute of East Asian Studies (Institut d'Asie Orientale; http://iao.ish-lyon.cnrs.fr/?lang=en)

Email: jean-pascal.bassino@ens-lyon.fr (corresponding author)

His research interests include Japanese quantitative economic history and the analysis of international business strategies in Asia. He has been affiliated with different academic institutions in France (University Montpellier 3, 1994-2002 and 2007-2011, University Grenoble 2, 20112013), as well as in Japan (Maison Franco-Japonaise and Hitotsubashi University, 2002-2005) and Australia (Australian National University, 2006-2007). Recent publications include: Fukao K, Bassino JP, Makino T, R. Paprzycki R, Settsu T, Takashima M, Tokui J, Regional inequality and industrial structure in Japan: 1874-2010. Tokyo, Maruzen, 2015; Bassino, JP, Dovis M, van der Eng P, "Do Japanese MNCs use expatriates to contain risk in Asian host countries?", Asia Pacific Business Review, 2015, 21 (3), 383-402).

Pablo Jensen is CNRS physicist at Ecole Normale Supérieure de Lyon (France), and member of IXXI (Institute of Complex Systems; http://www.ixxi.fr/accueil?set language=en\&cl=en)

Email: pablo.Jensen@ens-lyon.fr

He develops tools to conceptualize and analyze the dynamics of socio-economic complex systems. His recent publications in this field include: Venturini T, Jensen P, Latour B, "Fill in the Gap. A New Alliance for Social and Natural Sciences", J Artificial Societies and Social Simulations, March 2015; Jensen P, Paradzinets K, "The many dimensions of interdisciplinarity", Scientometrics 98 619-631 (2014); Bouchaud J-Ph, Borghesi Ch, Jensen P, "On the emergence of an 'intention field' for socially cohesive agents" J Stat Mech P03010 (2014); Remi Louf, Pablo Jensen, Marc Barthélémy, "Emergence of hierarchy in cost driven growth of spatial networks", Proceedings of the National Academy of Sciences (PNAS) 110 8824-8829 (2013).

Matteo Morini is $\mathrm{PhD}$ candidate in computer science at Ecole Normale Supérieure de Lyon (France); currently on leave from the Department of Economics and Statistics of the University of Torino (Italy).

Email: matteo.morini@ens-lyon.fr

His research interests are in the fields of Agent-Based Modelling, Complex Systems and Complex Networks. He teaches courses on Complexity and Agent-Based Models at the Collegio Carlo Alberto in Moncalieri (Italy). Recent publications include the book "Agent-based Models of the Economy: From Theories to Applications" (with Riccardo Boero, Michele Sonnessa, Pietro Terna), published by Palgrave Macmillan. 
Our study relies on micro-data obtained from the Toyo Keizai (TKZ) annual survey for analyzing the characteristics and evolution of network structures among Japanese manufacturing overseas subsidiaries since the 1960s. We focus on five ASEAN countries -- Indonesia, Malaysia, the Philippines, Singapore, and Thailand -- that have been among the main recipients of Japanese foreign direct investment since the 1960s, along with Hong Kong, Taiwan, and the United States (and China from the 1980s).

The aim of our study is to assess to what extent the Japanese business network structures in ASEAN countries replicated network structures existing in Japan in the same period, and evolved in the same manner. The TKZ database reports micro-data for several thousands Japanese overseas subsidiaries, either wholly owned companies or joint ventures with local partners. Available information enables identifying Japanese and non-Japanese shareholders, and the percentage of paid-up capital owned by each firm. Local partner companies were almost exclusively owned and operated by ethnic Chinese family-based networks (see for instance Suehiro (1992) on postwar Thailand). Ethnic Chinese business networks, initially specialized in trade, finance, and commodity processing, diversified their activities in the postwar period and played a major role in the development of the manufacturing sector in these ASEAN countries since the 1960s. The Chinese diaspora in ASEAN countries mainly originates from late $19^{\text {th }}$ and early $20^{\text {th }}$ century migrations from Guangdong and Fujian provinces. Therefore, we do not expect possible differences in the role of local partners of Japanese networks to be influenced by local cultural values but rather by local conditions, in particular ethnic tensions, political unrest, and sub-optimal institutions; and, in the case of the Philippines, national policies discouraging Japanese investment (Bassino and Williamson 2015).

The motivation for comparing Japanese networks in ASEAN countries and in Japan is related to one of the most hotly disputed issues in postwar Japan business history, namely the strength of postwar linkages between companies that belonged to one of the prewar conglomerates owned by kinship networks (i.e. zaibatsu such as Mitsui, Mitsubishi, Sumitomo, and Yasuda, dissolved in 1946 upon request of the U.S. occupation authorities). The major part of the academic community in the fields of management and industrial organization considers that the links between former zaibatsu companies remain strong in Japan during the postwar period and can be identified through information on main-bank, cross-ownership, and transactions (e.g. Gerlach 1992; Aoki and Saxonhouse 2000). This stream of literature also argues that the reconstitution of zaibatsu as socalled "horizontal keiretsu" (literally, keiretsu means "economic line-ups") in the 1950s and their persistence in the following decades relied on strong non-kinship interpersonal relationships among managers of the companies. Miwa and Ramseyer (Miwa and Ramseyer 2002; Ramseyer 2006) challenge this claim that they describe as an ideological construct devised by Japanese Marxists in the 1950s, later adopted by the Dodwell, a marketing company, and finally by non-Marxist scholars. They argue that the empirical evidence supporting the keiretsu hypothesis is weak. Our study tests the keiretsu hypothesis using data for ASEAN countries.

\section{References}

Aoki, M. and Saxonhouse G.R. eds. (2000). Finance, governance, and competitiveness in Japan. Oxford: Oxford University Press.

Bassino, J-P. and Williamson, J.G. (2015). "From commodity booms to economic miracles: why Southeast Asian industry lagged behind." CEPR Discussion Paper DP10611. Available at SSRN: http://ssrn.com/abstract=2610726

Gerlach, Michael L. (1992), Alliance capitalism: The social organization of Japanese business. Berkeley: University of California Press.

Miwa, Y. and Ramseyer, M. (2002) "The fable of the keiretsu," Journal of Economics \& Management Strategy, 11, 169-224. 
Ramseyer, M. (2006). The fable of the keiretsu: urban legends of the Japanese economy. Chicago: University of Chicago Press

Suehiro, A. (1992), "Capitalist development in postwar Thailand: commercial bankers, industrial elite, and agribusiness groups," in R. McVey (ed.), Southeast Asian Capitalists. Ithaca: Cornell University Press, $35-63$. 